\title{
Mathematical Macromodeling of Infilled Frames: State of the Art
}

\author{
P. G. Asteris, M.ASCE${ }^{1}$; S. T. Antoniou'²; D. S. Sophianopoulos, M.ASCE ${ }^{3}$; and C. Z. Chrysostomou ${ }^{4}$
}

\begin{abstract}
The primary objective of this paper is to present a general review of the different macromodels used for the analysis of infilled frames. A number of distinct approaches in the field of analysis of infilled frames since the mid-1950s have yielded several analytical models. These studies stressed that the numerical simulation of infilled frames is difficult and generally unreliable because of the very large number of parameters to be taken into account and the magnitude of the uncertainties associated with most of them. In this paper, the advantages and disadvantages of each macromodel are pointed out, and practical recommendations for the implementation of the different models are indicated. DOI: 10.1061/(ASCE)ST.1943-541X.0000384. ㅇ 2011 American Society of Civil Engineers.
\end{abstract}

CE Database subject headings: Failure modes; Frames; Masonry.

Author keywords: Failure modes; Infilled frames; Masonry; Macromodels.

\section{Introduction}

Unreinforced masonry (URM) infill walls in frame structures, also referred to in the literature as masonry-infill walls, have long been known to affect the strength and stiffness of infilled-frame structures. In seismic areas, ignoring the frame-infill panel interaction is not always safe, because under lateral loads the infill walls dramatically increase the stiffness by acting as a diagonal strut, resulting in a possible change of the seismic demand because of significant reduction in the natural period of the composite structural system (El-Dakhakhni et al. 2003, 2006). On the other hand, it is worth noticing that the contribution of the infill wall to the frame lateral stiffness is greatly reduced when the structure is subjected to reversed cyclic loading (as in real structures under earthquake conditions), in which case they have to undergo large nonlinear cycles. The relevant experimental findings (Vintzeleou and Tassios 1989; Paulay and Pristley 1992) showed a considerable reduction in the response of infilled frames under reversed cyclic loading. This behavior is caused by the rapid degradation of stiffness, strength, and low energy-dissipation capacity resulting from the brittle and sudden damage of the URM infill walls.

\footnotetext{
${ }^{1}$ Assistant Professor, Computational Mechanics Laboratory, Dept. of Civil and Construction Engineering, School of Pedagogical and Technological Education, N. Heraklion, Athens, Greece, GR 14121 (corresponding author). E-mail: pasteris@otenet.gr

${ }^{2}$ SeismoSoft Research and Development Director, SeismoSoftSoftware Solutions for Earthquake Engineering, Perikleous Stavrou St., Chalkis, Greece, GR 34100. E-mail: s.antoniou@ seismosoft.com

${ }^{3}$ Assistant Professor, Dept. of Civil Engineering, Univ. of Thessaly, Pedion Areos, Volos, Greece, GR 38334. E-mail: dimsof@civ.uth.gr

${ }^{4}$ Assistant Professor, Dept. of Civil Engineering and Geomatics, Cyprus Univ. of Technology, 3603 Lemesos, Cyprus. E-mail: c.chrysostomou@cut.ac.cy

Note. This manuscript was submitted on July 15, 2009; approved on January 13, 2011; published online on January 15, 2011. Discussion period open until May 1, 2012; separate discussions must be submitted for individual papers. This paper is part of the Journal of Structural Engineering, Vol. 137, No. 12, December 1, 2011. CASCE, ISSN 0733-9445/2011/12$1508-1517 / \$ 25.00$.
}

The rationale behind neglecting infill walls in the design process is partly the result of incomplete knowledge of the behavior of quasi-brittle materials such as URM and of the lack of conclusive experimental and analytical results to substantiate a reliable design procedure for this type of structure. On the other hand, because of the large number of interacting parameters, if the infill wall is to be considered in the analysis and design stages a modeling problem arises because of the many possible failure modes that need to be evaluated with a high degree of uncertainty. This is why it is not surprising that no consensus has emerged leading to a unified approach for the design of infilled frame systems, despite more than six decades of extensive experimental (Smith 1966; Smith and Carter 1969; Page et al. 1985; Mehrabi et al. 1996; Buonopane and White 1999; Santhi et al. 2005a, b) and semianalytical investigations (Liauw and Kwan 1984; Dhanasekar and Page 1986; Saneinejad and Hobbs 1995; Asteris 2003, 2005, 2008; Moghaddam 2004). However, it is generally accepted that under lateral loads an infill wall acts as a diagonal strut connecting the two loaded corners. Nevertheless, this is only applicable to the case of infill walls without openings on the diagonal of the infill panel.

An extensive review of the research on testing and modeling of masonry-infilled frames up until 1987 was reported by Moghaddam and Dowling (1987). A comprehensive review of the relevant literature published between 1987 and 1997 is presented by Madan et al. (1997) and an extensive and in-depth state-of-the-art report can be found in Crisafulli et al. (2000).

Recent advances in research (Žarnić et al. 2001; Moghaddam 2004; Hashemi and Mosalam 2006; Rodrigues et al. 2008; Dolšek and Fajfar 2008; Kose 2009) have shown that a strong interaction exists between an infill masonry wall and the surrounding frame, leading to the following:

- The behavior of the composite frame not only depends on the relative stiffness of the frame and the infill and the frame geometry, but is also critically influenced by the strength properties of the masonry;

- Considerable increase of the overall stiffness and the in-plane moment of inertia of the composite frame, as well as an increase of dissipated energy, provided they do not undergo large nonlinear cycles that cause both strength and stiffness degradation;

- Redistribution of action effects, and sometimes, unpredictable damage along the frame [in contrast, present code formulas 
overestimate the shear forces along the height of the frame because they do not consider the effect of infill panels (Santhi et al. 2005a, b)].

Approximately $80 \%$ of the structural cost from earthquakes is attributable to damage of infill walls and to consequent damage of doors, windows, and electrical and hydraulic installations (Tiedeman 1980). Despite its broad application and its economical significance, this system is considered nonstructural and is not included in analytical models. The following may explain this situation:

- Computational complexity: the discrete nature of masonry infill and the ever-changing contact conditions along its interface to the surrounding frame (made of either ductile material, e.g., steel, or brittle material, e.g., concrete) constitute additional sources of analytical burden. The real composite behavior of an infilled frame is a complex, statically indeterminate problem according to Smith (1966).

- Structural uncertainties: The mechanical properties of masonry and its wedging conditions against the internal surface of the frame depend strongly on local construction conditions.

- The nonlinear behavior of infilled frames depends on the interface conditions (integral, nonintegral, presence of gaps) between the masonry infill and the surrounding frame.

The objective of this paper is to review the most pertinent of the proposed analytical macromodels for the analysis of infilled frame structures and to point out the special challenges posed by the presence and complex action of infill panels, examples of which were mentioned previously. First, the behavior and failure modes of infilled frames are presented, followed by a description of the several macromodels, divided into single- and multiple-strut models. The analysis results obtained by a single-strut and a selected multiplestrut model are compared with experimental data, and finally some conclusions are drawn.

\section{Behavior of Infilled Frames}

The modeling of the behavior of infilled frames under lateral loading (and primarily earthquake-induced loads) is a complex issue because these structures exhibit a highly nonlinear response that is caused by the interaction of the masonry-infill panel and the surrounding frame. This results in several modes of failure, each of which has a different failure load and hence a different ultimate capacity and overall behavior.

At moderate loading levels, the infill of a nonintegral infilled frame separates from the surrounding frame, and the infill acts as a diagonal strut (Fig. 1). As the racking load is increased, failure occurs eventually in either the frame or the infill. The usual mode of frame failure results from tension in the windward column or from shearing on the column or beams (or plastic hinging in columns or beams); however, if the frame strength is sufficient enough to prevent its failure by one of these modes, the increasing racking load eventually produces failure of the infill. In the most common situations, the in-plane lateral load applied at one of the top corners is resisted by a truss formed by the loaded column and the infill along the diagonal connecting the loaded corner and the opposite bottom corner. The state of stress in the infill gives rise to a principal compressive stress along the diagonal, and a principal tensile stress in the perpendicular direction. If the infill is made of concrete, successive failures, initially by cracking along the compression diagonal and then by crushing near one of the loaded corners or by crushing alone, will lead to collapse; if the infill is made of brick masonry, an alternative possibility of shearing failure along the mortar planes may arise (Fig. 1).

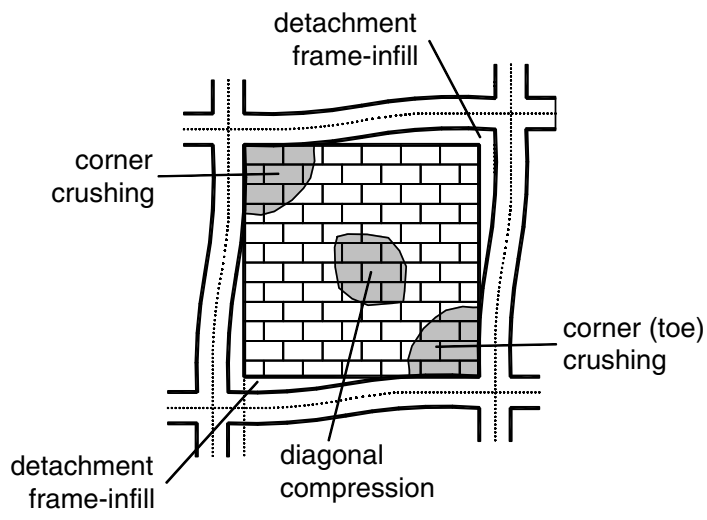

(a) CC mode; DC mode

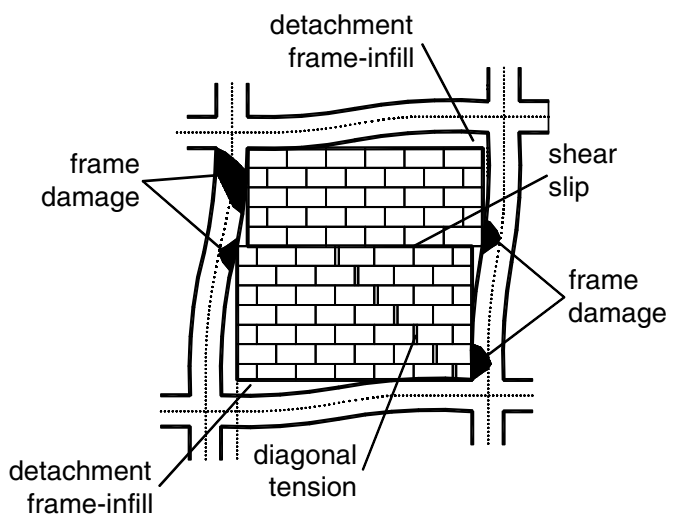

(b) SS mode; FF mode; DK mode

Fig. 1. Different failure modes of masonry-infilled frames: (a) corner crushing (CC) mode and diagonal compression (DK) mode; (b) sliding shear (SS) mode, frame failure (FF) mode, and diagonal cracking (DK) mode

Different failure modes of masonry-infilled frames were proposed on the basis of both experimental and analytical results produced during the last five decades (Thomas 1953; Wood 1958; Mainstone 1962; Liauw and Kwan 1983b; Mehrabi and Shing 1997), which can be classified into five distinct modes (Wood 1978; El-Dakhakhni 2002; Ghosh and Amde 2002; El-Dakhakhni et al. 2003). These are as follows:

1. The corner crushing (CC) mode, which represents crushing of the infill in at least one of its loaded corners, as shown in Fig. 1(a). This mode is usually associated with infilled frames consisting of a weak masonry-infill panel surrounded by a frame with weak joints and strong members (Mehrabi and Shing 1997; El-Dakhakhni 2002; Ghosh and Amde 2002; El-Dakhakhni et al. 2003).

2. The diagonal compression (DC) mode, which represents crushing of the infill within its central region, as shown in Fig. 1(a). This mode is associated with a relatively slender infill, in which failure results from out-of-plane buckling of the infill.

3. The sliding shear (SS) mode, which represents horizontal sliding-shear failure through bed joints of a masonry infill, as shown in Fig. 1(b). This mode is associated with an infill of weak mortar joints and a strong frame.

4. The diagonal cracking (DK) mode, which is seen in the form of a crack across the compressed diagonal of the infill panel and which often takes place with simultaneous initiation of the SS mode, as shown in Fig. 1(b). This mode is associated with a 
weak frame or a frame with weak joints and strong members infilled with a rather strong infill (Mehrabi and Shing 1997; El-Dakhakhni 2002).

5. The frame failure (FF) mode, which is seen in the form of plastic hinges developing in the columns or the beam-column connections, as shown in Fig. 1(b). This mode is associated with a weak frame or a frame with weak joints and strong members infilled with a rather strong infill.

Ghosh and Amde (2002) confirmed the order of occurrence of the five distinct failure modes based on the finite-element method and including interface elements at the frame-infill interface. Of the five modes, only the CC and SS modes are of practical importance [Comité Euro-International du Béton (CEB) 1996] because most infills are not slender (El-Dakhakhni et al. 2003) and the second mode (DC) is therefore not favored. The fourth mode (DK) should not be considered a failure mode because of the postcracking capacity of the infill to carry additional load. The fifth mode (FF) relates to the failure of the frame and it is particularly important when examining existing structures, which in many cases exhibit frame weakness. These failure modes are only seen or applicable to infill walls without openings on the diagonal of the infill panel.

On the basis of an analytical study of the seismic performance of masonry-infilled RC-framed structures, Kappos (2000) found that taking into account the infill in the analysis resulted in an increase in stiffness by as much as $440 \%$. Depending on the spectral characteristics of the design earthquake, the dynamic behavior of the two systems in the study (bare versus infilled frame) can be dramatically different. Kappos also presented a very useful global picture of the seismic performance of the studied infill frames by referring to the energy dissipated by each component of the structural system. At the serviceability level, more than $95 \%$ of the energy dissipation is taking place in the infill walls (subsequent to their cracking), whereas at higher levels, the RC members start making a significant contribution. This is a clear verification of the fact that masonry-infill walls act as a first line of defense in a structure subjected to earthquake load, whereas the RC frame system is crucial for the performance of the structure at stronger excitations (beyond the design earthquake).

\section{Macromodels}

Since the first attempts to model the response of the composite infilled frame structures, experimental and conceptual observations have indicated that a diagonal strut with appropriate geometrical and mechanical characteristics could possibly provide a solution to the problem. Early research on the in-plane behavior of infilled frame structures at the Building Research Station, Watford (subsequently renamed Building Research Establishment; now simply BRE) in the 1950s served as an early insight into this behavior and confirmed its highly indeterminate nature solely in terms of the normal parameters of design (Thomas 1953; Wood 1958; Mainstone 1962). On the basis of these few tests, a purely empirical interaction formula was subsequently tentatively suggested by Wood (1959) for use in the design of tall framed buildings. By expressing the composite strength of an infilled frame directly in the separate strengths of the frame and infill, he shortcircuited a mass of confusing detail, and recognized the desirability of a higher load factor in which strengths were most dependent on the infills.

\section{Diagonal-Strut Model}

In the early 1960s, Polyakov (1960) suggested the possibility of considering the effect of the infilling in each panel as equivalent to diagonal bracing. This suggestion was subsequently adopted by Holmes (1961), who replaced the infill with an equivalent pin-jointed diagonal strut made of the same material and having the same thickness as the infill panel and a width defined by

$$
\frac{w}{d}=\frac{1}{3}
$$

where $d$ = diagonal length of the masonry panel. The "one-third" rule was suggested as applicable irrespective of the relative stiffness of the frame and the infill. One year later, Smith (1962), based on experimental data from a large series of tests using masonry-infilled steel frames, found that the ratio $w / d$ varied from 0.10 to 0.25 . In the second half of the 1960s, Smith and his associates, using additional experimental data (Smith 1966, 1967; Smith and Carter 1969), related the width of the equivalent diagonal strut to the infill/frame contact lengths using an analytical equation, which has been adapted from the equation of the length of contact of a free beam on an elastic foundation subjected to a concentrated load (Hetenyi 1946). They proposed the evaluation of the equivalent width, $\lambda_{h}$, as a function of the relative panel-to-frame-stiffness parameter, in terms of

$$
\lambda_{h}=h \sqrt[4]{\frac{E_{w} t_{w} \sin 2 \theta}{4 E I h_{w}}}
$$

where $E_{w}=$ modulus of elasticity of the masonry panel; $E I=$ flexural rigidity of the columns; $t_{w}=$ thickness of the infill panel and equivalent strut; $h=$ column height between centerlines of beams; $h_{w}=$ height of infill panel; and $\theta=$ angle, whose tangent is the infill height-to-length aspect ratio, equal to

$$
\theta=\tan ^{-1}\left(\frac{h_{w}}{L_{w}}\right)
$$

in which $L_{w}=$ length of infill panel (all the precending parameters are explained in Fig. 2).

The use of this equation for seismic design is recommended for a lateral force level up to $50 \%$ of the ultimate capacity.

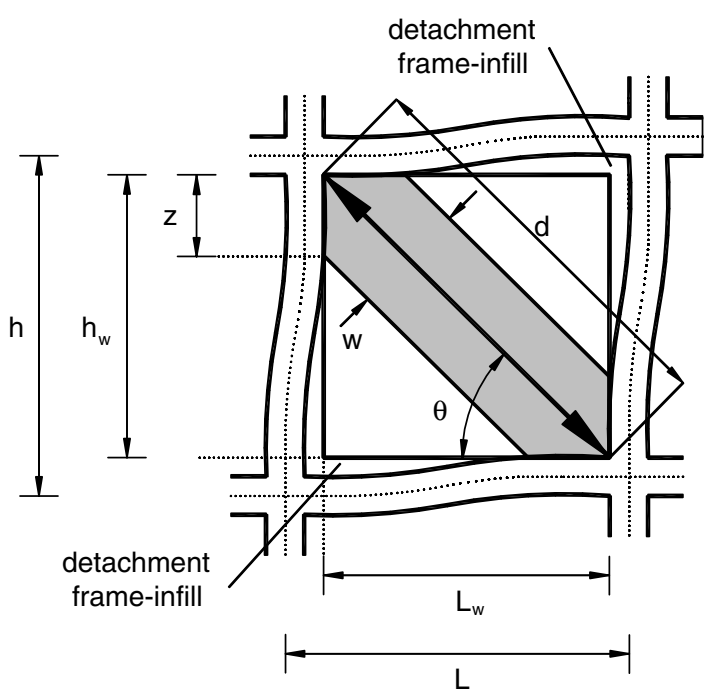

Fig. 2. Masonry-infill frame subassemblages 
Mainstone (1971) proposed an empirical equation for the calculation of the equivalent strut width on the basis of experimental and analytical data, given by

$$
\frac{w}{d}=0.16 \lambda_{h}^{-0.3}
$$

Mainstone and Weeks (1970) and Mainstone (1974), also on the basis of experimental and analytical data, proposed an empirical equation for the calculation of the equivalent strut width

$$
\frac{w}{d}=0.175 \lambda_{h}^{-0.4}
$$

This formula was included in FEMA-274 (FEMA 1997) for the analysis and rehabilitation of buildings, and in FEMA-306 (FEMA 1998) because it has been proved to be the most popular over the years. This equation was accepted from the majority of researchers dealing with the analysis of infilled frames (Klingner and Bertero 1978; Sobaih and Abdin 1988; Fardis and Calvi 1994; Negro and Colombo 1997; Fardis and Panagiotakos 1997; Kodur et al. 1995, 1998; Balendra and Huang 2003).

Bazan and Meli (1980), on the basis of parametric finite-element studies for one-bay, one-story, infilled frames, produced a diagram predicting the width of the equivalent strut for the case of failure (cracking) on the diagonal of infill panel. Tassios (1984) proposed a simple representation of the results of this diagram, given by

$$
\frac{w}{d} \cong 0.20 \sin \theta \sqrt{\frac{E_{c} A_{c}}{G_{w} A_{w}}} \text { if } 1<\frac{E_{c} A_{c}}{G_{w} A_{w}}<5
$$

Liauw and Kwan (1984), adopting values for the angle $\theta$ equal to $25^{\circ}$ and $50^{\circ}$ (typical for practical engineering purposes), also proposed a semiempirical expression for calculating the equivalent width, given by

$$
\frac{w}{d}=\frac{0.95 \sin 2 \theta}{2 \sqrt{\lambda_{h}}}
$$

The preceding semiempirical formula has been also adopted by many researchers for the modeling of infilled frames behavior (for example, by Crowley and Pinho 2006).

On the basis of results obtained from framed masonry under lateral loading, Decanini and Fantin (1987) proposed two sets of equations considering different states of the infill wall, given by

$$
\begin{gathered}
\text { Uncracked panel: } \frac{w}{d}= \begin{cases}0.085+\frac{0.748}{\lambda_{h}} & \text { if } \lambda_{h} \leq 7.85 \\
0.130+\frac{0.393}{\lambda_{h}} & \text { if } \lambda_{h}>7.85\end{cases} \\
\text { Cracked panel: } \frac{w}{d}= \begin{cases}0.010+\frac{0.707}{\lambda_{h}} & \text { if } \lambda_{h} \leq 7.85 \\
0.040+\frac{0.470}{\lambda_{h}} & \text { if } \lambda_{h}>7.85\end{cases}
\end{gathered}
$$

Paulay and Pristley (1992) pointed out that a high value of diagonal strut width will result in a stiffer structure, and therefore a potentially higher seismic response. They proposed a conservative value useful for seismic design of masonry-infilled frames given by

$$
\frac{w}{d}=\frac{1}{4}
$$

Durrani and Luo (1994), on the basis of empirical fitting of finite-element results and comparison with other models, proposed the following semiempirical formula for the calculation of the width of the equivalent strut:

$$
\frac{w}{d}=\gamma \sin 2 \theta
$$

in which parameters $\gamma$ and $m$ are given by

$$
\begin{gathered}
\gamma=0.32 \sqrt{\sin 2 \theta}\left(\frac{h^{4} E_{w} t_{w}}{m E_{c} I_{c} h_{w}}\right)^{-0.1} \\
m=6\left(1+\frac{6 E_{b} I_{b} h}{\pi E_{c} I_{c} L}\right)
\end{gathered}
$$

where $E_{c}$ and $E_{b}=$ elastic moduli of the frame column and beam material, respectively, and $I_{c}$ and $I_{b}=$ moments of inertia of the frame column and beam cross section, respectively. Recently, this formula was adopted by Perera (2005).

Flanagan and Bennet $(1999,2001)$ proposed a piecewise linear equivalent diagonal strut to model the infill walls based on the results of a number of full-scale clay infilled steel frames tested under in-plane loading. The behavior of the structural clay tile infills was correlated with the absolute story drift rather than with the nondimensional story drift. The area of the strut, $A$, is given by

$$
A=\frac{\pi t_{w}}{C \lambda \cos \theta}
$$

in which $C=$ empirical constant varying with the in-plane drift displacement, and serves as an indicator of the limit state of the infill. All the other parameters are defined in Eq. (2).

Fig. 3 illustrates the variation of the ratio $w / d$ according to a selection of the previous expressions. Holmes's proposition [Eq. (1)] gives an upper-bound value for the strut width, and Mainstone's proposition [Eq. (4)] a lower-bound one. On the other hand, the constant value suggested by Paulay and Pristley [Eq. (10)] gives a value that is more or less an average value of the two extremes. The equation proposed by Liauw and Kwan [Eq. (7)] covers the whole range of relative stiffnesses of infilled frames and gives values for the strut width that vary between the upper and lower bounds, as defined by the equations proposed by Holmes and Mainstone. The constant value proposed by Paulay and Pristeley applies for values of $\lambda_{h}$ less than 4 , whereas that proposed by Holmes applies for values of $\lambda_{h}$ less than 2 .

In their equivalent-strut model, Doudoumis and Mitsopoulou (1986) introduced new criteria to take into account the strength deterioration caused by cyclic loading. First, they assumed that the infill is not firmly connected to the frame at the beginning,

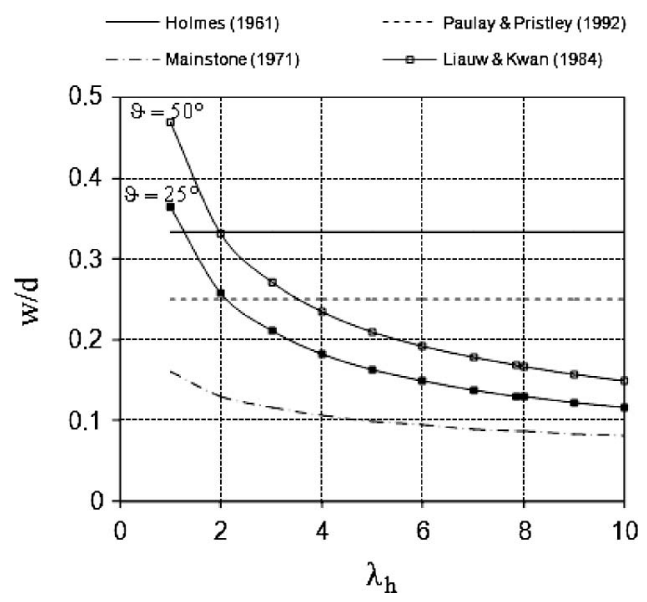

Fig. 3. Effective width as a function of the relative panel-to-framestiffness parameter $\lambda_{h}$ 
a fact implying that the strut remains inactive up to a certain level of deformation of the surrounding frame such as to close the initial gap at the interface due to shrinkage; second, they realized that the boundary conditions at the interface are unilateral, and hence no tensile stress may develop at the contact area. Their approach was implemented in the ANSR-I code (Mondkar and Powell 1975), through which numerical applications were performed on infilled frames under earthquake loading.

\section{Multiple-Strut Models}

In the preceding two decades, it has become clear that one singlestrut element is unable to model the complex behavior of the infilled frames. As reported by many researchers (Reflak and Fajfar 1991; Saneinejad and Hobbs 1995; Buonopane and White 1999), the bending moments and shearing forces in the frame members cannot be adequately represented by using a single diagonal strut connecting the two loaded corners. More complex macromodels were proposed, still typically based on a number of diagonal struts.

Thiruvengadam (1985) proposed the use of a multiple-strut model to simulate the effect of an infill panel. This model consists of a moment-resisting frame with a large number of pin-jointed diagonal and vertical struts. Initially, a perfect frame-infill bond condition is assumed, and the lateral stiffness of the infill by its shear deformation is modeled by a set of pin-ended diagonal struts running in both directions. These diagonals represent the shear and axial stiffness of the masonry infill. Similarly, the vertical stiffness contribution is accounted for by providing vertical struts. The lateral strains attributable to the effect of Poisson's ratio are neglected. The objective of the aforementioned study was a realistic evaluation of the natural frequencies and modes of vibration, purposes for which the nonlinear phenomena do not play an important role. Because of the great number of struts, this model has been adopted by many researchers to investigate the effect of infill on the behavior of infilled frames (Chaker and Sherifati 1999; Singh and Das 2006) as a method for modeling the special case of infilled frames with openings, and was also included in FEMA-356 (FEMA 2000). Similarly, Hamburger and Chakradeo (1993) proposed a multistrut configuration that can also account for the openings, but the evaluation of the characteristics of the struts is rather complicated. They showed that for panels of typical configuration, the formation of these struts protects the beam-to-column connections, which are of limited strength from significant flexural demand, with plastic hinges forming instead within the midspan region of the beam. They postulated that this resulted in a system of significant strength, stiffness, and ductility that behaves much like modern eccentric-braced frame systems. Such behavior could, in part, be responsible for the observed good performance of these buildings in the 1906 San Francisco earthquake (Hamburger and Meyer 2006).

The primary advantage of the multiple-strut models, despite the increase in complexity, is the ability to represent the actions in the frame more accurately. Syrmakezis and Vratsanou (1986) employed five parallel struts in each diagonal direction. It was stressed how different contact lengths have a significant effect on the bending moment distribution in the frame members.

Chrysostomou (1991) and Chrysostomou et al. (2002) aimed to obtain the response of infilled frames under earthquake loading by taking into account both stiffness and strength degradation of infills. He proposed to model each infill panel by six compressiononly inclined struts (Fig. 4). Three parallel struts were used in each diagonal direction, and the off-diagonal ones were positioned at critical locations along the frame members. These locations are specified by parameter $\alpha$, which represents a fraction of the length or height of a panel and is associated with the position of the

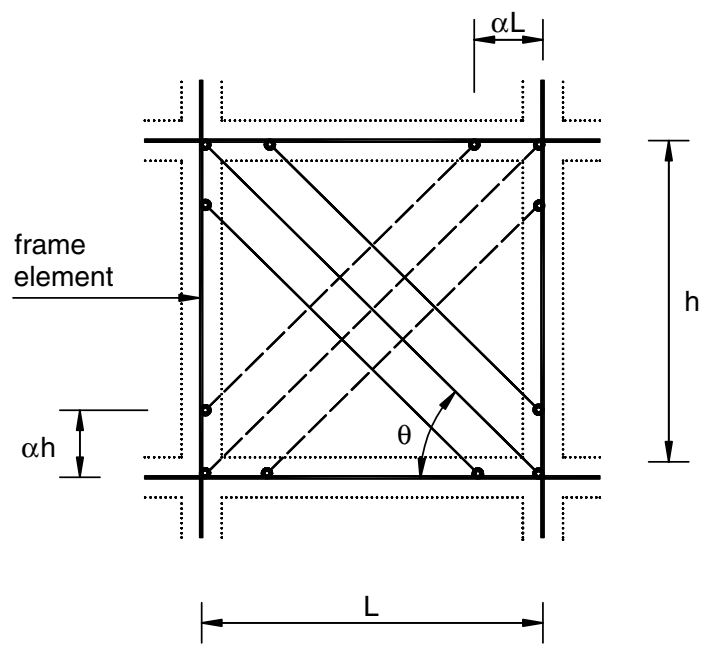

Fig. 4. Six-strut model for masonry-infill panel in frame structures (Chrysostomou 1991)

formation of a plastic hinge in a beam or a column. Theoretical values for this parameter are given by Liauw and Kwan (1983a, b, 1984). At any point during the analysis of the nonlinear response, only three of the six struts are active, and the struts are switched to the opposite direction whenever their compressive force reduced to zero.

To conduct a nonlinear analysis, the force-displacement relationships corresponding to the equivalent-strut model must be adequately defined. The modeling of hysteretic behavior increases not only the computational complexity but also the uncertainties of the problem (Klingner and Bertero 1976; Andreaus et al. 1985; Doudoumis and Mitsopoulou 1986; Chrysostomou et al. 1990).

In Chrysostomou's model, the hysteretic behavior of the six struts is defined by a hysteretic model consisting of two equations. The first equation defines the strength envelope of a structural element; the second defines its hysteretic behavior. The shape of the envelope and the hysteretic loops is controlled by six parameters, which all have physical meaning and can be obtained from experimental data. More details about the model are presented by Chrysostomou (1991) in his Ph.D. thesis. The advantage of this strut configuration over the single diagonal strut is that it allows the modeling of the interaction between the infill and the surrounding frame, and takes into account both strength and stiffness degradation of the infill, which is vital for determining the response of infilled frames subjected to earthquake load.

Saneinejad and Hobbs (1995) developed a method based on the equivalent diagonal strut approach for the analysis and design of steel or concrete frames with concrete or masonry-infill walls subjected to in-plane forces. The proposed analytical model assumes that the contribution of the infill panel to the response of the infilled frame can be modeled by "replacing the panel" with a system of two diagonal masonry compression struts. The method takes into account the elastoplastic behavior of infilled frames, considering the limited ductility of infill materials. Various governing factors, such as the infill aspect ratio, the shear stresses at the infill-frame interface, and relative beam and column strengths are accounted for in this development. This model was adopted by Madan et al. (1997) for static monotonic loading and quasi-static cyclic loading. In the aforementioned paper, the model was also successfully verified by simulating the experimental behavior of tested masonryinfill-frame subassemblage. This model for masonry-infill panels was implemented in IDARC 2D (IDARC 2D Version 4.0), a 
computer-based analytical tool for the inelastic analysis and damage evaluation of buildings and their components under combined dynamic, static, and quasi-static loading. The infill panel element integrated in IDARC 2D may be specified in any bay of the principal frames.

El-Dakhakhni (2000, 2002) and El-Dakhakhni et al. (2001) suggested a modeling technique for concrete masonry-infilled steel frames, as shown in Fig. 5. The technique is based on replacing the infill wall by one diagonal and two off-diagonal struts, making use of the orthotropic behavior of the masonry wall, and experimental observations and analytical simplifications in order to simplify the nonlinear modeling of these structures.

Crisafulli (1997) investigated the influence of different multistrut models on the structural response of reinforced concrete infilled frames, focusing on the stiffness of the structure and the actions induced in the surrounding frame. Numerical results, obtained from the single-, two-, and three-strut models, were compared with those corresponding to a refined finite element. The lateral stiffness of the structure was similar in all the cases considered, with smaller values for two- and three-strut models. For the multistrut models, the stiffness may change significantly depending on the separation between struts. The single-strut model underestimates the bending moment because the lateral forces are primarily resisted by a truss mechanism. On the other hand, the two-strut model leads to larger values than those corresponding to the finiteelement model. A better approximation is obtained from the threestrut model (Fig. 4), although some differences arise at the ends of both columns. Although the single-strut model constitutes a sufficient tool for the prediction of the overall response and the triple-strut model is superior in precision, Crisafulli adopted the double-strut model approach, accurate enough and less complicated compared to the other models.

More recently, Crisafulli and Carr (2007) proposed a new macromodel to represent, in a rational but simple way, the effect of masonry-infill panels. The model is implemented as a four-node panel element that is connected to the frame at the beam-column joints. Internally, the panel element accounts separately for the compressive and shear behavior of the masonry panel using two parallel struts and a shear spring in each direction, as shown in Fig. 6. This configuration allows an adequate consideration of the lateral stiffness of the panel and of the strength of masonry panel, particularly when a shear failure along mortar joints or

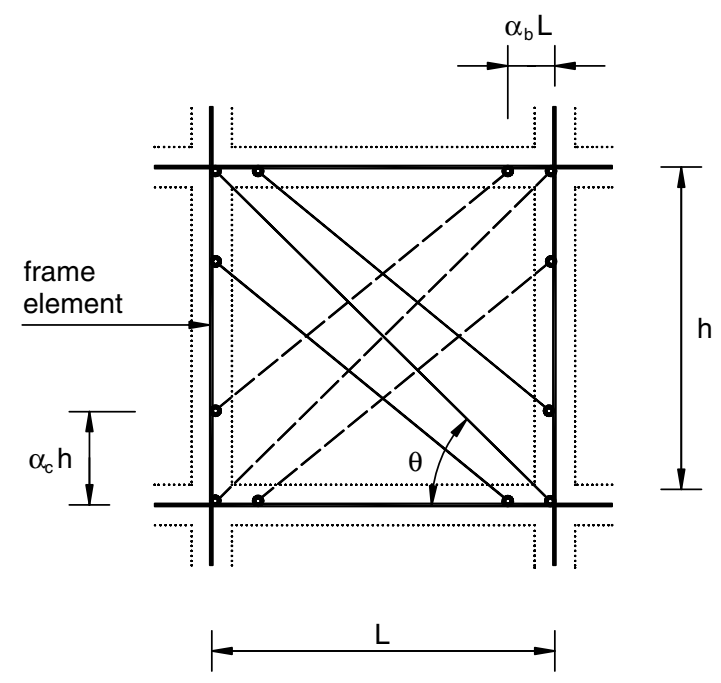

Fig. 5. Six-strut model for masonry-infill panel (El-Dakhakhni 2000, 2002; El-Dakhakhni et al. 2001)

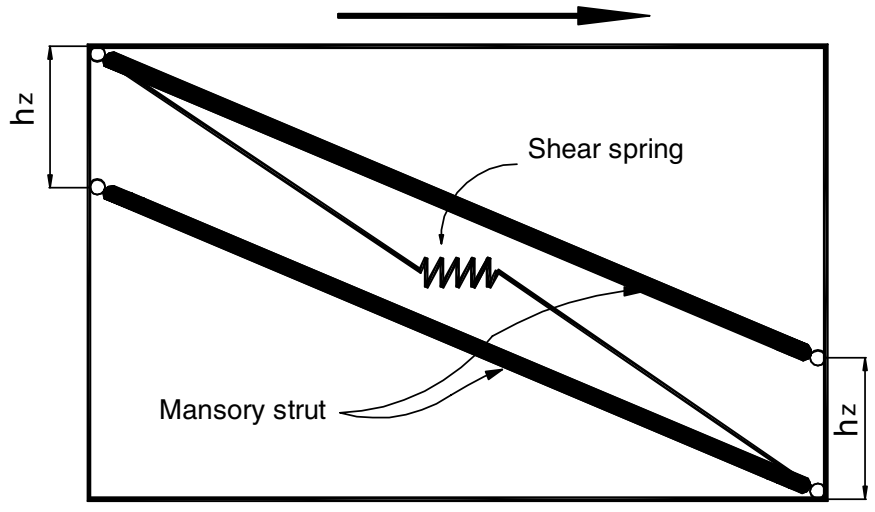

Fig. 6. Multistrut model proposed by Crisafulli and Carr (2007) for masonry-infill panel (only the struts and the shear spring active in one direction are represented)

diagonal tension failure is expected. Furthermore, the model is easy to apply in the analysis of large infilled frame structures. The primary limitation of the model results from its simplicity. The panel is connected to the beam-column joints of the frame, so the model is not able to properly predict the bending moment and shear forces in the surrounding frame. The proposed model for masonryinfill panels was implemented in RUAUMOKO (Carr 2000), a computer-based analytical tool able to accurately model threedimensional structures while providing ancillary design data such as earthquake spectra. The proposed model has been also implemented in the program SeismoStruct (Seismostruct), and numerical results were compared to experimental data by Smyrou (2006) and Smyrou et al. (2006), showing the accuracy of the model in evaluateing the nonlinear response of the structure. Furthermore, they conducted an interesting sensitivity analysis to evaluate the relative importance of the parameters used in the model to represent the cyclic response of masonry.

\section{Comparison of Response of Different Strut Models}

One of the difficulties that practicing engineers face is the reliable modeling of infilled frames with openings. Although the singlestrut model can be used to represent with sufficient accuracy the behavior of solid infill walls, its applicability to infill walls with openings requires its calibration using finite-element analysis (FEMA 2000).

To illustrate the inadequacy of simple single-strut models for representing the structural response of infill walls with openings in frame structures, a case study was carried out employing a reinforced concrete frame, whereby the infill walls were modeled with each of the two approaches. For the multistrut case, the Crisafulli double-strut model was chosen because it is satisfactorily precise for accurately representing the local effect between the infill and the frame, and is less complicated than a triple-strut model. The single-strut model used is a rather "gross" model that can be employed in commercial packages. It consists of a pair of diagonal elastic struts that are active at all times, each of which has a stiffness of $50 \%$ of the calculated infill-wall stiffness.

The relative accuracy of the models is assessed through comparison with experimental results obtained from pseudodynamic tests of a full-scale, four-story, three-bay, reinforced concrete frame, which was tested at the European Laboratory for Structural Assessment (ELSA) reaction-wall laboratory within the framework of the Innovative Seismic Design Concepts for New and Existing Structures (ICONS) research program (Pinto et al. 2002). The frame was infilled with brick walls that included 


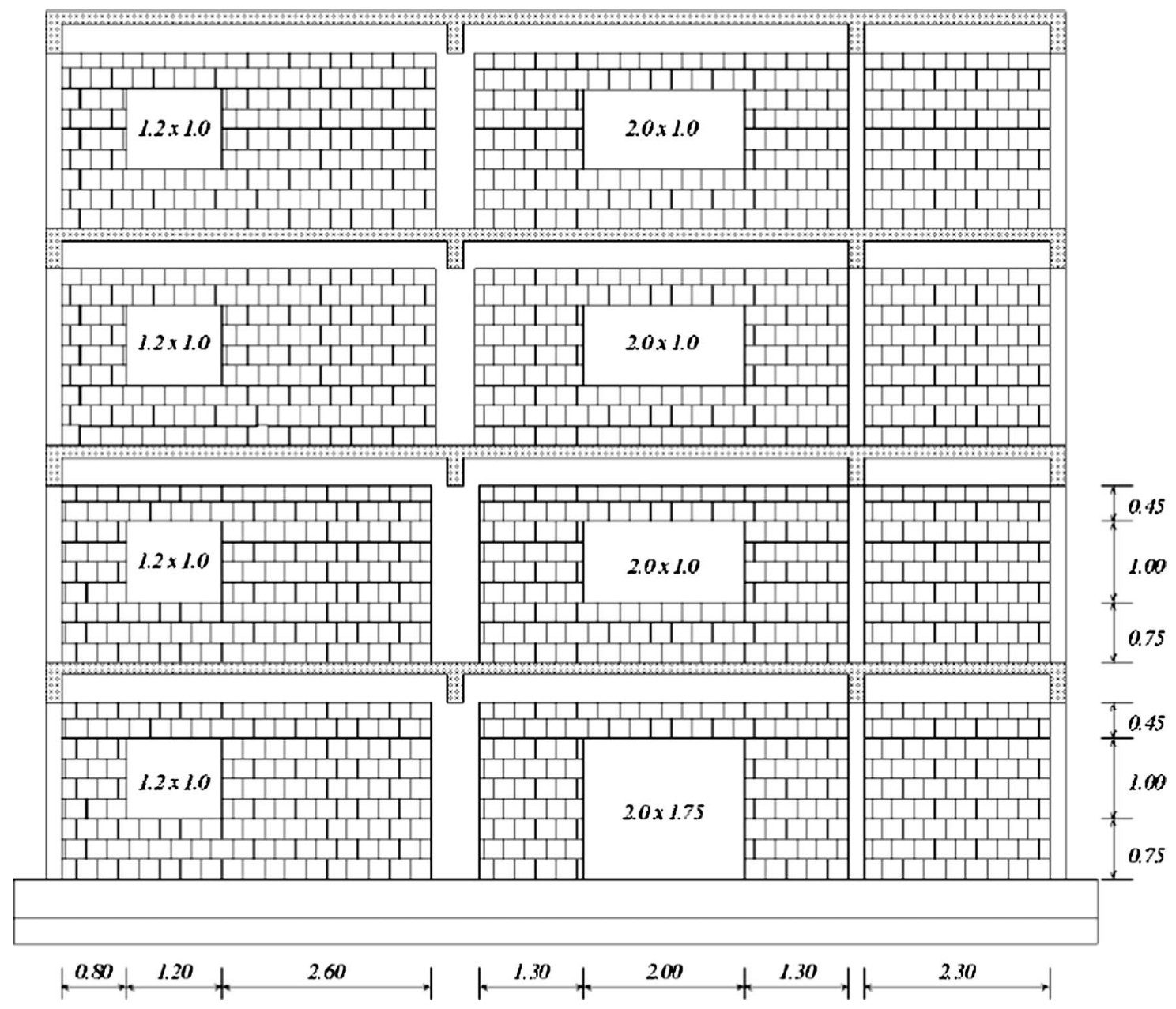

Fig. 7. Elevation view of the infilled frame with location and dimensions (in $\mathrm{m}$ ) of openings (Pinto et al. 2002, with permission)

openings of different dimensions (Fig. 7). It can be regarded as representative of the design and construction practice of the $1960 \mathrm{~s}$ in Southern Europe, designed to withstand only vertical loads, without satisfying modern seismic-code design requirements.

The experimental seismic response was obtained with pseudodynamic testing, i.e., a step-by-step integration technique to compute the displacement response of the frame that was subjected to three different, numerically specified seismic records, utilizing the nonlinear restoring forces actually developed during the test. The input seismic motions were chosen to be representative of a moderately high European hazard scenario. The acceleration time histories were artificially generated (Campos-Costa and Pinto 1999), and three increasing return periods of 475, 975, and 2,000 years were used for the experiment (only the first two were employed in the present study).

The nonlinear structural analysis program SeismoStruct (SeismoStruct) was employed for the analyses. SeismoStruct is an Internet-downloadable fiber-based finite-element package capable of predicting the large displacement behavior of space frames under static or dynamic loading, considering both geometric

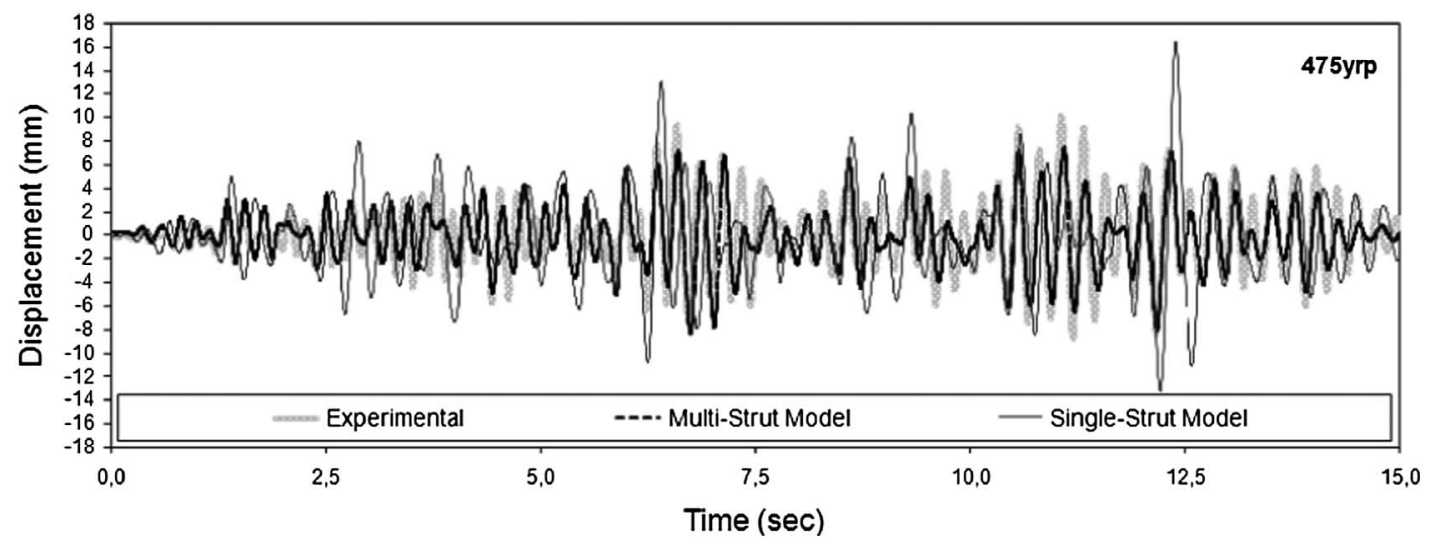

Fig. 8. Comparison of the top displacement of the infilled frame and the two structural models (475 year return period record) 
nonlinearities and material inelasticity and fully accounting for the spread of inelasticity along the member length and across the section depth.

Representative numerical results obtained from the single and multistrut models are depicted in Fig. 8. It can be concluded that the multistrut model provides a very good fit to the experimental results, and better approximation with the use of finite elements is hardly justified. However, it should be stressed that the correct modeling of the infills required the selection of the value of a significant number of parameters, a difficult and intricate task that is not always appropriate in everyday practice.

Conversely, the single-strut model lacks a similar ability to adequately represent the experimental behavior, providing significantly less accurate results. This is entirely attributed to the inability of such oversimplified models to reproduce all the complex aspects of the infill walls' behavior. Conclusions similar to the preceding have been drawn regarding the displacement and the shear-force profiles along the height of the building.

\section{Conclusions}

The primary objective of this paper is to present a general review of the different macromodels used for the analysis of infilled frames. A brief summary of the main parameters affecting the behavior of infilled frames that should be taken into account in mathematical models is presented that shows the complexity of the problem at hand. This complexity increases because in most cases, infills contain openings that considerably affect the behavior of infilled frames and hence their modeling.

Regarding the five possible failure modes of infills, there is a consensus that only the corner-crushing and sliding-shear modes are of practical importance, provided there are no openings in the infill. The mode of frame failure may be also considered, as it has been observed to occur many times in the field. Regarding the other two, namely, diagonal compression and diagonal cracking, the first occurs very rarely because it requires a high slenderness ratio of the infill, and the second should not be considered a failure mode because the infill can carry additional load after it cracks. The out-of-plane failure is an additional mode that should be considered, especially for double leaf walls.

With these complexities in mind, a number of researchers have attempted to model infill frames over the last 60 years. The macromodels that can be used in everyday engineering are of practical importance. The simpler ones are the equivalent-strut models, which represent infills with a diagonal strut element. The basic parameter of these struts is their equivalent width, which affects their stiffness and strength. Several formulas have been proposed by researchers to calculate this equivalent width. In all the cases, there are considerable differences among the values obtained. The equation that has been adopted by most technical guidelines is the one proposed by Mainstone (1974). Compared to other proposed formulas, this formula represents a lower bound of the calculated equivalent strut width.

Noting that single-strut models are inadequate for accurately representing the interaction between the infill and the bounding frame and thus cannot accurately predict the force distribution in the members of the bounding frame, researchers have made attempts to represent infill walls with multiple struts. Models with two, three, and more than three struts have been proposed. The merits and shortcomings of each of these models have been discussed in this paper, showing that the three-strut models can more accurately predict the infill-frame interaction than the single-strut ones, but with a considerable increase in modeling complexity; whereas the two-strut models, although they cannot achieve the accuracy of the three-strut models, improve the prediction compared to the single struts, with less model complexity. The multiple-strut models also have the advantage of being able to take into account the presence of openings in infills, either through their load-displacement and hysteretic models for the two- and threestrut models, or through the positioning of the struts for models with more than three struts.

A single-strut model and a two-strut model were used to study their capability to reproduce the results of an ICONS research program in which a full-scale, four-storey, three-bay, masonry-infilled $\mathrm{RC}$ frame was tested under pseudodynamic testing conditions at the ELSA laboratory in Ispra (Pinto et al. 2002). The results indicated that the two-strut model was able to capture the behavior of the tested infilled frame with openings better than the singlestrut model.

Despite this 60-year-long effort, it is evident that the available macromodels for infill walls do not possess the necessary simplicity and the required accuracy to be used in everyday engineering practice. The single-strut model, although very simple to implement in general-purpose finite-element commercial software, fails to capture the interaction between the bounding frame and the infill wall, and unless there is a hysteretic model defined, it cannot be used for response history analysis. On the other hand, multiple-strut models, although they can provide better modeling of both the infill and its interaction with the bounding frame, cannot be used in a general-purpose finite-element software because of the complexities involved in their implementation.

Therefore, it can be concluded that the issue of modeling infill walls is still an open one, despite the long and rigorous attention that it has received from the research community over the years. The highly variable nature of the material, the large number of parameters involved, and in particular the presence of openings in infill walls makes the modeling of this structural element very difficult; in most of the cases it is therefore considered a nonstructural one. The significant contribution of infill walls in the behavior of infilled frames makes imperative the continuation of research in this area in order to provide everyday models that will be able to accurately capture the behavior of infilled frames.

\section{Acknowledgments}

The writers would like to acknowledge the suggestions of the editor of the Journal of Structural Engineering, Professor Sashi K. Kunnath, on the structure of this paper.

\section{References}

Andreaus, U., Gerone, M., D’Asdia, P., and Iannozzi, F. (1985). “A finite element model for the analysis of masonry structures under cyclic actions." Proc., 7th Int. Brick Masonry Conf., Vol. 1, Univ. of Melbourne, Melbourne, Australia, 479-488.

Asteris, P. G. (2003). "Lateral stiffness of brick masonry infilled plane frames." J. Struct. Eng., 129(8), 1071-1079.

Asteris, P. G. (2005). "Closure to 'Lateral stiffness of brick masonry infilled plane frames' by P. G. Asteris.” J. Struct. Eng., 131(3), 523-524.

Asteris, P. G. (2008). "Finite element micro-modeling of infilled frames." Electron. J. Struct. Eng., 8, 1-11.

Balendra, T., and Huang, X. (2003). "Overstrength and ductility factors for steel frames designed according to BS 5950." J. Struct. Eng., 129(8), 1019-1035.

Bazan, E., and Meli, R. (1980). "Seismic analysis of structures with masonry walls." Proc., 7th World Conf. on Earthquake Engineering, Vol. 5, International Association of Earthquake Engineering (IAEE), Tokyo, 633-640. 
Buonopane, S. G., and White, R. N. (1999). "Pseudodynamic Testing of Masonry Infilled Reinforced Concrete Frame." J. Struct. Eng., 125(6), 578-589.

Campos-Costa, A., and Pinto, A. V. (1999). European seismic hazard scenarios-An approach to the definition of input motions for testing and reliability assessment of civil engineering structures, European Laboratory for Structural Assessment (ELSA), Ispra, Italy.

Carr, A. J. (2000). "RUAUMOKO: Inelastic dynamic analysis." Univ. of Canterbury Dept. of Civil Engineering, 〈http://www.ruaumoko.co.nz〉.

Chaker, A. A., and Sherifati, A. (1999). "Influence of masonry infill panels on the vibration and stiffness characteristics of R/C frame buildings." Earthquake Eng. Struct. Dyn., 28(9), 1061-1065.

Chrysostomou, C. Z. (1991). "Effects of degrading infill walls on the nonlinear seismic response of two-dimensional steel frames." Ph.D. thesis, Cornell Univ., Ithaca, NY.

Chrysostomou, C. Z., Gergely, P., and Abel, J. F. (1990). "Preliminary studies on the effects of degrading infill walls on the non-linear seismic response of steel frames." Proc., 4th National Conf. on Earthquake Engineering, Vol. 2, Earthquake Engineering Research Institute (EERI), Oakland, CA, 229-238.

Chrysostomou, C. Z., Gergely, P., and Abel, J. F. (2002). "A six-strut model for nonlinear dynamic analysis of steel infilled frames." Int. J. Struct. Stab. Dyn., 2(3), 335-353.

Comité Euro-International du Béton (CEB). (1996). "RC frames under earthquake loading." State of the Art Rep., CEB, Paris.

Crisafulli, F. G. (1997). "Seismic behaviour of reinforced concrete structures with masonry infills." Ph.D. thesis, Univ. of Canterbury, Christchurch, New Zealand.

Crisafulli, F. J., and Carr, A. J. (2007). "Proposed macro-model for the analysis of infilled frame structures." Bull. New Zealand Soc. Earthquake Eng., 40(2), 69-77.

Crisafulli, F. J., Carr, A. J., and Park, R. (2000). "Analytical modelling of infilled frame structures-A general review." Bull. New Zealand Soc. Earthquake Eng., 33(1), 30-47.

Crowley, H., and Pinho, R. (2006). "Simplified equations for estimating the period of vibration of existing buildings." Proc., 1st European Conf. on Earthquake Engineering and Seismology, European Association for Earthquake Engineering (EAEE), Istanbul, Turkey.

Decanini, L. D., and Fantin, G. E. (1987). "Modelos simplificados de la mampostería incluida en porticos. Características de rigidez y resistencia lateral en astado límite." Jornadas Argentinas de Ingeniería Estructural III, Vol. 2, Asociacion de Ingenieros Estructurales, Buenos Aires, Argentina, 817-836 (in Spanish).

Dhanasekar, M., and Page, A. W. (1986). "Influence of brick masonry infill properties on the behaviour of infilled frames." ICE Proc., 81(4), 593-605.

Dolšek, M., and Fajfar, P. (2008). "The effect of masonry infills on the seismic response of a four-storey reinforced concrete frame-A deterministic assessment." Eng. Struct., 30(7), 1991-2001.

Doudoumis, I. N., and Mitsopoulou, E. N. (1986). "Non-linear analysis of multistorey infilled frames for unilateral contact conditions." Proc., 8th European Conf. on Earthquake Engineering, European Association for Earthquake Engineering (EAEE), Istanbul, Turkey, 63-70.

Durrani, A. J., and Luo, Y. H. (1994). "Seismic retrofit of flat-slab buildings with masonry infills." Proc., NCEER Workshop on Seismic Response of Masonry Infills, National Center for Earthquake Engineering Research (NCEER), Buffalo, NY.

El-Dakhakhni, W. W. (2000). "Non-linear finite element modeling of concrete masonry-infilled steel frame." M.S. thesis, Civil and Architectural Engineering Dept., Drexel Univ., Philadelphia.

El-Dakhakhni, W. W. (2002). "Experimental and analytical seismic evaluation of concrete masonry-infilled steel frames retrofitted using GFRP laminates." Ph.D. thesis, Drexel Univ., Philadelphia.

El-Dakhakhni, W. W., Elgaaly, M., and Hamid, A. A. (2001). "Finite element modeling of concrete masonry infilled steel frame." 9th Canadian Masonry Symp., National Research Council (NRC), Ottawa, Canada.

El-Dakhakhni, W. W., Elgaaly, M., and Hamid, A. A. (2003). "Three-strut model for concrete masonry-infilled frames." J. Struct. Eng., 129(2), 177-185.
El-Dakhakhni, W. W., Hamid, A. A., Hakam, Z. H. R., and Elgaaly, M. (2006). "Hazard mitigation and strengthening of unreinforced masonry walls using composites." Compos. Struct., 73(4), 458-477.

Fardis, M. N., and Calvi, O. M. (1994). "Effects of infills on the global response of reinforced concrete frames." Proc., 10th European Conf. on Earthquake Engineering, European Association for Earthquake Engineering (EAEE), Istanbul, Turkey, 2331-2336.

Fardis, M. N., and Panagiotakos, T. B. (1997). "Seismic design and response of bare and masonry-infilled reinforced concrete buildings. Part II: Infilled structures." J. Earthquake Eng., 1(3), 475-503.

FEMA. (1997). "NEHRP commentary on the guidelines for the seismic rehabilitation of buildings." FEMA-274, Washington, DC.

FEMA. (1998). "Evaluation of earthquake damaged concrete and masonry wall buildings: Basic procedures manual." FEMA-306, Washington, DC

FEMA. (2000). "Prestandard and commentary for the Seismic Rehabilitation of Buildings." FEMA-356, Washington, DC.

Flanagan, R. D., and Bennett, R. M. (1999). "In-plane behaviour of structural clay tile infilled frames." J. Struct. Eng., 125(6), 590-599.

Flanagan, R. D., and Bennett, R. M. (2001). "In-plane analysis of masonry infill materials." Pract. Period. Struct. Des. Constr., 6(4), $176-182$.

Ghosh, A. K., and Amde, A. M. (2002). "Finite element analysis of infilled frames." J. Struct. Eng., 128(7), 881-889.

Hamburger, R. O., and Chakradeo, A. S. (1993). "Methodology for seismic-capacity evaluation of steel-frame buildings with infill unreinforced masonry." Proc., National Earthquake Conf., Vol. 2, Central U.S. Earthquake Consortium, Memphis, TN, 173-191.

Hamburger, R. O., and Meyer, J. D. (2006). "The performance of steelframe buildings with infill masonry walls in the 1906 San Francisco earthquake." Earthquake Spectra, 22(S2), S43-S67.

Hashemi, A., and Mosalam, K. M. (2006). "Shake-table experiment on reinforced concrete structure containing masonry infill wall." Earthquake Eng. Struct. Dyn., 35(14), 1827-1852.

Hetenyi, M. (1946). Beams on elastic foundations, University of Michigan Press, Ann Arbor, MI.

Holmes, M. (1961). "Steel frames with brickwork and concrete infilling." ICE Proc., 19(4), 473-478.

IDARC $2 D$ Version 4.0 [Computer software]. National Center for Earthquake Engineering Research (NCEER), Buffalo, NY.

Kappos, A. J. (2000). "Seismic design and performance assessment of masonry infilled RC frames." Proc., 12th World Conf. on Earthquake Engineering, International Association of Earthquake Engineering (IAEE), Tokyo.

Klingner, R. E., and Bertero, V. V. (1976). "Infilled Frames in EarthquakeResistant Construction.” Rep. No. EERC 76-32, Univ. of California, Berkeley, CA.

Klingner, R. E., and Bertero, V. V. (1978). "Earthquake resistance of infilled frames." J. Struct. Div., 104(ST6), 973-989.

Kodur, V. K. R., Erki, M. A., and Quenneville, J. H. P. (1995). "Seismic design and analysis of masonry-infilled frames." Can. J. Civ. Eng., 22(3), 576-587.

Kodur, V. K. R., Erki, M. A., and Quenneville, J. H. P. (1998). "Seismic analysis of infilled frames." J. Struct. Eng., 25(2), 95-102.

Kose, M. M. (2009). "Parameters affecting the fundamental period of RC buildings with infill walls." Eng. Struct., 31(1), 93-102.

Liauw, T. C., and Kwan, K. H. (1983a). "Plastic theory of infilled frames with finite interface shear strength." ICE Proc., 75(4), 707-723.

Liauw, T. C., and Kwan, K. H. (1983b). "Plastic theory of non-integral infilled frames." ICE Proc., 75(3), 379-396.

Liauw, T. C., and Kwan, K. H. (1984). "Nonlinear behaviour of nonintegral infilled frames." Comput. Struct., 18, 551-560.

Madan, A., Reinhorn, A. M., Mander, J. B., and Valles, R. E. (1997). "Modeling of masonry infill panels for structural analysis." J. Struct. Eng., 123(10), 1295-1302.

Mainstone, R. J. (1962). "Discussion on steel frames with brickwork and concrete infilling." ICE Proc., 23, 94-99.

Mainstone, R. J. (1971). "On the stiffnesses and strengths of infilled frames.” Proc., ICE Suppl., Vol. 4, Building Research Station, Garston, UK, 57-90. 
Mainstone, R. J. (1974). Supplementary note on the stiffness and strengths of infilled frames, Building Research Station, Garston, UK.

Mainstone, R. J., and Weeks, G. A. (1970). "The influence of bounding frame on the racking stiffness and strength of brick walls." Proc., 2nd Int. Brick Masonry Conf., Building Research Establishment, Watford, England, 165-171.

Mehrabi, A. B., and Shing, P. B. (1997). "Finite element modeling of masonry-infilled RC frames." J. Struct. Eng., 123(5), 604-613.

Mehrabi, A. B., Shing, P. B., Schuller, M., and Noland, J. (1996). "Experimental evaluation of masonry-infilled RC frames." J. Struct. Eng., 122(3), 228-237.

Moghaddam, H. A. (2004). "Lateral load behavior of masonry infilled steel frames with repair and retrofit." J. Struct. Eng., 130(1), 56-63.

Moghaddam, H. A., and Dowling, P. J. (1987). "The state of the art in infilled frames." ESEE Research Rep. No. 87-2, Imperial College of Science and Technology, Civil Engineering Dept., London, UK.

Mondkar, D. P., and Powell, G. H. (1975). "ANSR-I: General purpose program for analysis of nonlinear structural response." UCB/EERC-75/37, Earthquake Engineering Research Center, Univ. of California, Berkeley, CA, 145.

Negro, P., and Colombo, A. (1997). "Irregularities induced by nonstructural masonry panels in framed buildings." Eng. Struct., 19(7), 576-585.

Page, A. W., Kleeman, P. W., and Dhanasekar, M. (1985). "An in-plane finite element model for brick masonry." Proc., Structures Congress, ASCE, Reston, VA, 1-18.

Paulay, T., and Pristley, M. J. N. (1992). Seismic design of reinforced concrete and masonry buildings, Wiley, New York, 744.

Perera, R. (2005). "Performance evaluation of masonry-infilled RC frames under cyclic loading based on damage mechanics." Eng. Struct., 27(8), $1278-1288$.

Pinto, A., Verzeletti, G., Molina, J., Varum, H., Pinho, R., and Coelho, E. (2002). Pseudo-dynamic tests on non-seismic resisting $R C$ frames (bare and selective retrofit frames), Joint Research Centre (JRC), Ispra, Italy.

Polyakov, S. V. (1960). "On the interaction between masonry filler walls and enclosing frame when loading in the plane of the wall." Translation in earthquake engineering, Earthquake Engineering Research Institute (EERI), San Francisco, 36-42.

Reflak, J., and Fajfar, P. (1991). "Elastic analysis of infilled frames using substructures." Proc., 6th Canadian Conf. on Earthquake Engineering, University of Toronto Press, Toronto, 285-292.

Rodrigues, H., Varum, H., and Costa, A. (2008). "A non-linear masonry infill macro-model to represent the global behaviour of buildings under cyclic loading." Int. J. Mech. Mat. Des., 4(2), 123-135.

Saneinejad, A., and Hobbs, B. (1995). "Inelastic design of infilled frames." J. Struct. Eng., 121(4), 634-650.

Santhi, M. H., Knight, G. M. S., and Muthumani, K. (2005a). "Evaluation of seismic performance of gravity load designed reinforced concrete frames." J. Perform. Constr. Facil., 19(4), 277-282.

Santhi, M. H., Knight, G. M. S., and Muthumani, K. (2005b). "Evaluation of seismic response of soft-storey infilled frames." Comput. Concr., 2(6), 423-437.
SeismoStruct. [Computer software]. SeismoSoft, Pavia, Italy.

Singh, Y., and Das, D. (2006). "Effect of URM infills on seismic performance of RC frame buildings." Proc., 4th Int. Conf. on Earthquake Engineering,, Center for Urban Earthquake Engineering (CUEE), Tokyo.

Smith, B. S. (1962). "Lateral stiffness of infilled frames." J. Struct. Div., 88(6), 183-199.

Smith, B. S. (1966). "Behavior of square infilled frames." J. Struct., 92(1), 381-403.

Smith, B. S. (1967). "Methods for predicting the lateral stiffness and strength of multi-storey infilled frames." Build. Sci., 2(3), 247-257.

Smith, B. S., and Carter, C. (1969). "A method of analysis for infilled frames." ICE Proc., 44(1), 31-48.

Smyrou, E. (2006). "Implementation and verification of a masonry panel model for nonlinear dynamic analysis of infilled RC frames." M.S. dissertation, European School for Advanced Studies in Reduction of Seismic Risk, Universita degli Studi di Pavia, Pavia, Italy.

Smyrou, E., Blandon-Uribe, C., Antoniou, S., Pinho, R., and Crowley, H. (2006). "Implementation and verification of a masonry panel model for nonlinear pseudo-dynamic analysis of infilled RC frames." Proc., 1st European Conf. on Earthquake Engineering and Seismology, European Association for Earthquake Engineering (EAEE), Istanbul, Turkey.

Sobaih, M., and Abdin, M. M. (1988). "Seismic analysis of infilled reinforced concrete frames." Comput. Struct., 30(3), 457-464.

Syrmakezis, C. A., and Vratsanou, V. Y. (1986). "Influence of infill walls to RC frames Response." Proc., 8th European Conf. on Earthquake Engineering, European Association for Earthquake Engineering (EAEE), Istanbul, Turkey, 47-53.

Tassios, T. P. (1984). "Masonry infill and RC walls (an invited state-ofthe-art report)." 3rd Int. Symp. on Wall Structures, Centre for Building Systems, Research and Development, Warsaw, Poland.

Thiruvengadam, V. (1985). "On the natural frequencies of infilled frames." Earthquake Eng. Struct. Dyn., 13(3), 401-419.

Thomas, F. G. (1953). "The strength of brickwork." Struct. Eng., 31(2), 44-46.

Tiedeman, H. (1980). "A statistical evaluation of the importance of nonstructural damage to buildings." Proc., 7th World Conf. on Earthquake Engineering, Vol. 6, International Association of Earthquake Engineering (IAEE), Tokyo, 617-624.

Vintzeleou, E., and Tassios, T. P. (1989). "Seismic behaviour and design of infilled RC frames." Euro. Earthquake Eng., 2, 22-28.

Wood, R. H. (1958). "The stability of tall buildings." ICE Proc., 11, 69-102.

Wood, R. H. (1959). "Discussion on the stability of tall buildings." ICE Proc., 12, 502.

Wood, R. H. (1978). "Plasticity, composite action and collapse design of unreinforced shear wall panels in frames." ICE Proc., 65, 381-411.

Žarnić, R., Gostič, S., Crewe, A. J., and Taylor, C. A. (2001). "Shaking table tests of 1:4 reduced-scale models of masonry infilled reinforced concrete frame buildings." Earthquake Eng. Struct. Dyn., 30(6), 819-834. 